\title{
A CORRELATIVE STUDY ON SERUM LIPID PROFILE AND OSTEOGENIC MINERAL STATUS IN OSTEOPOROSIS
}

\author{
Deepika Lahon', Munin Borgohain², Barnali B. Thakur ${ }^{3}$ \\ ${ }^{1}$ Associate Professor, Department of Biochemistry, Gauhati Medical College \& Hospital, Guwahati, Assam. \\ 2 Associate Professor, Department of Orthopaedics, Fakhruddin Ali Ahmed Medical College \& Hospital, Jatigaon, Barpeta, Assam. \\ ${ }^{3}$ Assistant Professor, Department of Biochemistry, Gauhati Medical College \& Hospital, Guwahati, Assam.
}

\section{ABSTRACT}

\section{BACKGROUND}

Osteoporosis is a condition where the structural and functional integrity of the bones are altered to an extent where the bone material is not sufficiently completed enough to perform its basic function of support, load bearing and component of metabolic pool of osteogenic minerals.

\section{METHODS}

The study was conducted in a group of 50 women ( 25 cases and 25 controls) irrespective of age from different socio-economic status. As per plan of study, the target population was divided into two main groups. The first group was defined as the control group and the other group as the experimental or test group who were admitted in orthopaedic unit of Gauhati Medical College and Ho spital with different type of clinical manifestations of osteoporotic disease, the diagnosis of which were made on the basis of $\mathrm{x}$-ray findings, provided the clinical examination and laboratory procedures are in agreement.

\section{RESULTS}

In our study, the mean fasting serum TG, HDL and VLDL values are significantly high $(\mathrm{P}<0.01)$ and the LDL value is significantly low in the women with osteoporosis in relation to normal control group. Total cholesterol values in osteoporotic group is apparently $6.07 \%$ lower than the mean total cholesterol in the normal control group. Osteogenic minerals represented by calcium, phosphate and magnesium show significant elevation $(\mathrm{P}<0.01)$ of mean serum concentration in the osteoporotic group than the normal control group.

\section{CONCLUSION}

Observed changes and relationship between the lipid profile and mineral status in serum in osteoporosis are indicative of an ongoing rearranging process in an altered metabolism, which is primarily aimed at diminishing its pace towards the associated complications indicated by attempted lowering of circulating cholesterol and maintenance of serum minerals within normal limits with assistance from a hormonal axis composed of components from metabolic-reproductive hormonal axis responsible for modulating natural aging process.

\section{KEYWORDS}

Osteoporosis, Lipid Profile, Osteogenic Minerals, Menopause, Aging.

HOW TO CITE THIS ARTICLE: Lahon D, Borgohain M, Thakur BB. A correlative study on serum lipid profile and osteogenic mineral status in osteoporosis. J. Evolution Med. Dent. Sci. 2016;5 (23):1243-1250, DOI: 10.14260/jemds/2016/290

\section{INTRODUCTION}

Osteoporosis is the most common metabolic bone disease in the world. It is the second leading cause of musculoskeletal morbidity in elderly. By definition it is an abnormal reduction in bone tissue mass per unit volume of anatomical bone.[1] causing skeletal weakness, although the ratio of mineral to organic elements is unchanged. Osteoporosis is a chronic and progressive metabolic disorder of bone characterized by micro architectural deterioration of bone tissue resulting in increased fragility.[2] Beginning with menopause, women experience accelerated bone loss for about 5-7 years.[3] There is reduction in the number and size of the trabeculae and in the number of osteoblasts present, which leads to fracture or crushes with minor trauma.[4]

Financial or Other, Competing Interest: None.

Submission 07-01-2016, Peer Review 18-02-2016,

Acceptance 26-02-2016, Published 19-03-2016.

Corresponding Author:

Dr. Munin Borgohain,

Bahniman Path, $\mathrm{H} / \mathrm{No}-8$

Near Jayanagar L. P. School,

Beltola, Guwahati-28,

Assam.

E-mail: deepikagmc08@gmail.com

DOI: $10.14260 /$ jemds/2016/290
Primary osteoporosis is mainly a disease of the elderly which may be again of two types:

1. Postmenopausal osteoporosis Type I (10-20 years) of menopause.

2. Senile osteoporosis Type II (Aged over 70 years).

3. Idiopathic osteoporosis, which is uncommon but occur in children and young adults of both sexes with normal gonadal function.

Within these different etiological groups of osteoporosis, the late postmenopausal period and age above 70 years is the most susceptible period of life for osteoporotic changes. The common link between these two vulnerable groups for osteoporosis is the definite change in the overall hormonal status associated with menopause and aging.

Oestrogen deficiency is a significant cause of accelerated bone loss in the perimenopausal state and affects circulating levels of specific cytokines. ${ }^{5}$ Postmenopausal women with a family history of fractures will probably encounter future problem. ${ }^{6}$ The major clinical manifestations of osteoporosis are bone fractures, which cause chronic pain. The remodelling process takes place on bone surfaces in discrete packets known as basic multicellular units. ${ }^{7}$ In normal individuals, peak bone mass is reached at age 25-35 years and thereafter a decrease with age occurs in both sexes. ${ }^{8}$ 
Bones in a dynamic state serve as a reservoir of calcium. ${ }^{9}$ The internal metabolism and homeostasis of calcium and phosphate are controlled by PTH, Calcitonin and Vitamin D, all of which act to maintain concentrations of physiologically active ionized calcium and phosphate. ${ }^{10}$ Calcitonin secretion is lower in women than in men and declines with age, which leads to excessive bone resorption in women.11 Oestrogen deficiency both directly and indirectly decreases the efficiency of intestinal and renal calcium absorption and resorption respectively.12 In support of most of these views on the relationship among osteoporosis, hormonal state and mineral state, most of the workers on the problem suggest changing oestrogen status with the aging process as one of the primary hormonal component. ${ }^{13}$

Lipid profile level increases with increasing age in women, particularly after menopause and osteoporosis more predominantly occurs in the postmenopausal women. So we want to explore a more clear picture regarding osteoporosis and changes in lipid profile, keeping in mind that changes in hormonal profile is a primary factor for both these conditions.

\section{Objectives of the Study}

Objective of the study was: (1) To determine the relationship between changes in lipid profile and osteogenic mineral status in osteoporotic individual and to probe the scope for utilization of the interpreted data in formulation of a more rational management of osteoporosis. (2) To interpret the observed affects in association with available information on the related problem regarding osteoporosis.

\section{MATERIALS AND METHODS}

The present study was conducted in a group of 50 female subjects ( 25 cases and 25 controls) irrespective of age taken randomly from different socioeconomic status. As per plan of study, the target population was divided into two main groups. The first group was defined as the control group and the other group as the experimental group or the test group. Experimental or the test group was composed of 25 female patients suffering from osteoporosis based on clinical diagnosis and investigative procedures. Subjects for the control group were selected randomly among women of the different sectors of the society belonging to different occupation and socioeconomic status, co-operating voluntarily. Control group consists of 25 female subjects.

A careful screening was done in selecting the subjects, so that the subjects having any history of pathological fracture, hypertension, diabetes mellitus, cardiac disease, peripheral vascular disease, hepatobiliary disease, renal disorders either in the past or present was not included in this group. Cases taken in the present study for the experimental group were amongst those who were admitted in orthopaedic unit of Gauhati Medical College and Hospital from February 2015 to May 2015 with different types of clinical manifestations of osteoporotic disease, the diagnosis of which were made on the basis of x-ray findings, clinical examinations and laboratory procedures.

\section{Methods of Evaluations}

All the biochemical estimations were done by using colorimetric principle in a computer assisted semiautomatic BOEHRINGER 4020 photometer.
The serum was separated and centrifuged for $3 \mathrm{~min}$. at $3000 \mathrm{rpm}$ in a clinical centrifuge machine.

\section{Sample Analysis}

Serum triglyceride was estimated by the reagent kits of $\mathrm{Dr}$ Reddy's based on glycerol-3-phosphate oxidase peroxidase method developed by Fossati and Prenicipe. Serum cholesterol was determined by reagent kit of Dr Reddy's dependent on enzymatic method with endpoint suitable for colorimetric estimation. HDL cholesterol was determined by the reagent kit based on the cholesterol oxidase and precipitation method. The "Friedewald" formula was utilized to calculate out the serum VLDL from the estimated serum triglyceride level as follows.

VLDL-Cholesterol in $\mathrm{mg} / \mathrm{dL}=\mathrm{TG} / 5$. For determination of serum LDL cholesterol, values of serum total cholesterol, HDL cholesterol and serum triglyceride levels were estimated again by utilizing "Friedewald's" formula, serum LDL cholesterol was calculated.

LDL-Cholesterol in $\mathrm{mg} / \mathrm{dL}=$ Total cholesterol (TC)(HDL+VLDL) cholesterol.

Serum inorganic phosphate was estimated by Delsal and Manhouri method (1958), which is a modified method introduced by Gomori in 1942. Protein free filtrate is treated with ammonium molybdate, which reacts with inorganic phosphate to form phosphomolybdenum compound. The hexavalent molybdenum is reduced by means of methyl aminophenol sulphate to give a blue coloured compound, which is estimated colorimetrically. Serum magnesium was estimated by colorimetric method using titan yellow. Serum calcium was determined by the reagent kit of Zydus based on Cresolphthalein complexone method, initially described by Anderegg et al. Serum urea and creatinine were measured by using commercially available assay kits by modified Berthelot method and modified Jaffe's Kinetic method respectively. Serum glucose was estimated by the reagent kit of Dr. Reddy's dependent on glucose oxidase/peroxidase method.

\section{Ethics}

The study was approved by Ethics Committee of Gauhati Medical College (GMC).

\section{Statistical Analysis}

The results of all the biochemical estimations were statistically analysed and compared between different groups of the study by applying student's " $t$ " test to evaluate the changes of serum lipid profile and minerals $\left(\mathrm{Ca}, \mathrm{Po}_{4}, \mathrm{Mg}\right.$.) in osteoporosis along with few correlation studies depending on preliminary results obtained within some relevant groups.

\section{RESULTS}

The details of the results and observations are as follows: Age

In the normal control group (25 female subjects), the age varied within the range of 20-70 years with a mean age of $34.6 \pm 2.50$ and a median age of 32 years. Maximum number of subjects are in the class interval of 20-40 years with a relative frequency of 0.632 .

In the diseased group, comprising of 25 female subjects the age varied within the range of 40-70 years with a mean age of $61.6 \pm 1.58$ and a median age of 60 years. 
Maximum number of subjects are in the class interval of 41-60 years with a relative frequency of 0.560 .

\section{Sex}

In the normal control group there are 25 healthy female subjects and in the diseased group there are 25 female subjects suffering from osteoporosis.

\section{Serum Total Cholesterol}

In the normal group, the total cholesterol values ranges from 103 to $216 \mathrm{mg} / \mathrm{dL}$. The mean value is $167.96 \pm 6.44 \mathrm{mg} / \mathrm{dL}$ and the median value is $176 \mathrm{mg} / \mathrm{dL}$. The maximum number of subjects in normal groups have cholesterol activity in the class interval $151-200 \mathrm{mg} / \mathrm{dL}$ with relative frequency of occurrence 0.597 . The minimum number of subjects in this group have total cholesterol in the interval of $101-150 \mathrm{mg} / \mathrm{dL}$ with relative frequency of occurrence 0.033 .

In the patient group, the total cholesterol values ranges from $82-272 \mathrm{mg} / \mathrm{dL}$ : the mean value is $157.76 \pm 8.54 \mathrm{mg} / \mathrm{dL}$ and the median value is $155 \mathrm{mg} / \mathrm{dL}$. The maximum number of subjects in this group have total cholesterol activity in the class interval of $151-200 \mathrm{mg} / \mathrm{dL}$ with relative frequency of occurrence 0.522 . The minimum number of subjects in this group has total cholesterol in the interval of $51-100 \mathrm{mg} / \mathrm{dL}$ with relative frequency of occurrence 0.042 .

\section{Serum Triglyceride}

In the normal control group, the serum triglyceride values ranges from $52-180 \mathrm{mg} / \mathrm{dL}$. The mean value is $127.32+6.89 \mathrm{mg} / \mathrm{dL}$ and the median value is $133 \mathrm{mg} / \mathrm{dL}$. The maximum number of subjects in this group have serum TG activity in the class interval of $101-150 \mathrm{mg} / \mathrm{dL}$ with relative frequency of occurrence 0.542 , whereas in the patient group mean value is $156.2+6.88$ and the median value is $153 \mathrm{mg} / \mathrm{dL}$, maximum number of subjects have serum TG activity in the class interval of $151-200 \mathrm{mg} / \mathrm{dL}$ with relative frequency of occurrence 0.494 . So triglyceride values are significantly high in the osteoporotic group than normal control group.

\section{Serum HDL Cholesterol}

In the normal control group, the HDL cholesterol values ranges from $25-44 \mathrm{mg} / \mathrm{dL}$ with mean value of $35.6+/-1.00 \mathrm{mg} / \mathrm{dL}$. Maximum number of subjects in this group have serum HDL cholesterol activity in the class interval of $31-40 \mathrm{mg} / \mathrm{dL}$ with relative frequency of occurrence 0.059 . On the other hand in the patient group serum HDL values ranges from $13-62 \mathrm{mg} / \mathrm{dL}$, the mean value is $43.16 \pm 2.27 \mathrm{mg} / \mathrm{dL}$. The maximum number of subjects in patient's group have serum HDL cholesterol activity in the class interval of $31-40 \mathrm{mg} / \mathrm{dL}$ with relative frequency of occurrence 0.332 .

Serum VLDL cholesterol: In the normal control group, the serum VLDL cholesterol values ranges from $10.4 \pm 35.8 \mathrm{mg} / \mathrm{dL}$, the mean value is $25.39 \pm 1.43 \mathrm{mg} / \mathrm{dL}$. Maximum number of subjects in control group have serum VLDL activity in the class interval of $21-30 \mathrm{mg} / \mathrm{dL}$ with relative frequency of occurrence 0.550 . But in the patient group VLDL cholesterol ranges from $18-41 \mathrm{mg} / \mathrm{dL}$ and the mean value is $30.4+1.41 \mathrm{mg} / \mathrm{dL}$, the median value is $30 \mathrm{mg} / \mathrm{dL}$ and maximum number of subjects in osteoporotic group have serum VLDL cholesterol activity in the class interval of $21-30 \mathrm{mg} / \mathrm{dL}$ with relative frequency of occurrence 0.41 .
Serum LDL cholesterol values in the control group ranges from 61.6 to $152.0 \mathrm{mg} / \mathrm{dL}$ and the maximum number of subjects in this group have serum LDLc activity in the class interval of $101-150 \mathrm{mg} / \mathrm{dL}$ with relative frequency of occurrence 0.748 . (Mean values $109.06 \pm 4.67 \mathrm{mg} / \mathrm{dL}$ ).

In the patient group, serum LDL cholesterol values ranges from $38-113 \mathrm{mg} / \mathrm{dL}$ and maximum number of subjects in this group have serum LDL cholesterol activity in the class interval of $51-100 \mathrm{mg} / \mathrm{dL}$ with a relative frequency of occurrence 0.521 . Only this parameter is low in patients with osteoporosis than the mean values of normal control. (Mean values of patients $81.44 \pm 4.87$ ).

\section{Serum Calcium}

In control group values ranges from $8-10 \mathrm{mg} / \mathrm{dL}$ with mean value $9.16 \pm 0.124$ and the maximum number of subjects in this group have serum calcium activity in the class interval of 8.1$9 \mathrm{mg} / \mathrm{dL}$ with relative frequency of occurrence 0.589 .

In the patient group values ranges from $8.8-10.3 \mathrm{mg} / \mathrm{dL}$ with mean value $9.74 \pm 0.101 \mathrm{mg} / \mathrm{dL}$ and maximum number of subjects in this group have serum calcium activity in the class interval of $10.1-11.0 \mathrm{mg} / \mathrm{dL}$ with relative frequency of occurrence 0.501 .

Serum Phosphate: In control group, the values ranges from $1.2-4.2 \mathrm{mg} / \mathrm{dL}$ with mean value $2.95 \pm 0.132$ and the maximum number of subjects in this control group have serum phosphate activity in the class interval of $2.8-3.5 \mathrm{mg} / \mathrm{dL}$ with relative frequency of occurrence 0.515 .

In the patient group, values ranges from $2.5-4.2 \mathrm{mg} / \mathrm{dL}$ with mean value $3.28 \pm 0.082 \mathrm{mg} / \mathrm{dL}$ and maximum number of subjects in this group have serum phosphate activity in the class interval of $2.8-3.5 \mathrm{mg} / \mathrm{dL}$ with relative frequency of occurrence 0.582 .

\section{Serum Magnesium}

In normal control group, the serum magnesium values ranges from $1.8-2.5 \mathrm{mg} / \mathrm{dL}$ with mean value $2.20 \pm 0.044$ and maximum number of subjects in this group have serum magnesium activity in the class interval of $2-2.3 \mathrm{mg} / \mathrm{dL}$ with relative frequency of occurrence 0.459 .

In patient group, the values ranges from $2.1-3.3 \mathrm{mg} / \mathrm{dL}$ with mean value $2.49 \pm 0.064 \mathrm{mg} / \mathrm{dL}$ and the maximum number of subjects in this group have serum magnesium activity in the class interval of $2-2.3 \mathrm{mg} / \mathrm{dL}$ with relative frequency of occurrence 0.323 .

Serum glucose: In control group, values ranges from 60 $95 \mathrm{mg} / \mathrm{dL}$ with mean value $79.88 \pm 1.49 \mathrm{mg} / \mathrm{dL}$ and the maximum number of subjects in this group have serum glucose activity in the class interval of $71-80 \mathrm{mg} / \mathrm{dL}$ with relative frequency of occurrence 0.583 .

In the patient group values ranges from $82-128 \mathrm{mg} / \mathrm{dL}$ with the mean value of $97.36 \pm 2.31 \mathrm{mg} / \mathrm{dL}$ and the maximum number of subjects in this group have serum glucose activity in the class interval of $101-200 \mathrm{mg} / \mathrm{dL}$ with relative frequency of occurrence 0.446 .

\section{Serum Creatinine}

In the normal control group, the values ranges from 0.7 $1.2 \mathrm{mg} / \mathrm{dL}$ with the mean value $0.95 \pm 0.032$ and the maximum number of subjects in this group have serum creatinine activity in the class interval of $0.8-1.0 \mathrm{mg} / \mathrm{dL}$ with relative frequency of occurrence 0.529 . 
In the patient group, serum creatinine values ranges from $0.7-1.4 \mathrm{mg} / \mathrm{dL}$ with mean value $1.02 \pm 0.035 \mathrm{mg} / \mathrm{dL}$ and the maximum number of subjects in this group have serum creatinine activity in the class interval of $0.8-1.0 \mathrm{mg} / \mathrm{dL}$ with relative frequency of occurrence 0.458 .

\section{Serum Urea}

In the normal control group, the serum urea values ranges from $22-32 \mathrm{mg} / \mathrm{dL}$ the mean value is $26.04+0.514 \mathrm{mg} / \mathrm{dL}$ and the median is $26 \mathrm{mg} / \mathrm{dL}$. In the patient group serum urea values ranges from $22-67 \mathrm{mg} / \mathrm{dL}$, the mean value is $33.0+1.85$ $\mathrm{mg} / \mathrm{dL}$ and the median value is $32 \mathrm{mg} / \mathrm{dL}$.

Present study shows a statistically significant increase in TG, HDL and VLDL in osteoporotic group compared with normal control group $(\mathrm{P}<0.01)$ Tab 2, 3, 4.

LDL cholesterol is significantly low in osteoporotic group (Tab 5), Fig. 1(B).

No significant difference is observed between mean serum total cholesterol values in two groups (Tab 1), Fig. 1(C).

The group of osteogenic minerals represented by $\mathrm{Ca} 2+$, $\mathrm{P} 3$-and $\mathrm{Mg} 2+$ show significant elevation $(\mathrm{P}<0.01)$ of mean serum concentrations in the osteoporotic group than the corresponding mean values of the control group (Tab 6, 7, 8), Fig. 1(D).

The mean fasting serum concentrations of glucose in the osteoporotic group show very highly significant increase in comparison to the normal control group (Tab 9).

From the foregoing observations and discussions on the present study, it may be summarily infarct that the osteoporotic group is basically neither frankly hyperlipidemic nor osteogenic dismineralostatic in terms of fasting serum concentrations with respect to normal reference intervals in a population without any clinical osteoporotic evidence. It may be reemphasized again that all the significant changes observed in the osteoporotic group are well within the normal reference interval and the significance of deviation is only with respect to the differences in the mean values with the normal control of the present study. Under the prevailing situation in the present study the lipid profile of the osteoporotic group may be redesignated as basically targeted to minimize cholesterol transport to the periphery and maximize cholesterol scavenging system from the periphery as indicated by lowered circulating total cholesterol and LDL-c with elevated circulating HDLc. In the osteoporotic group, the osteogenic minerals are significantly elevated within the normal reference interval indicating an enhanced rate of mineral turnover between bone and blood, but within the normal limits of renal functions.

The mean serum urea in the osteoporotic group is elevated with very high significance $(\mathrm{P}<0.001)$ than normal control. But the serum urea levels in both the groups are well within the clinically normal reference interval (Tab 10).

The mean serum creatinine between the control and osteoporotic group does not show any significant differences $(\mathrm{P}>0.01)$ Tab 11.

\section{DISCUSSION}

Osteoporosis is a chronic and progressive metabolic disorder of bone, characterized by microarchitectural deterioration of bone tissue resulting in increased fragility. In normal bone, bone formation and bone resorption are closely coupled.
Osteoporosis is unfortunately common, affecting over 20 million people in the United States alone. ${ }^{14}$

Our study was carried out in the Department of Orthopaedics, Gauhati Medical College and Hospital, Guwahati, Assam. The distribution pattern of the age in both the groups shows to balance of the condition as per previously reported age groups as one of the etiological factor of osteoporosis.[15] In the normal control group the highest frequency is observed between the age group 20-40 years, which is explained by the fact that during selection of the control group most of the volunteers are within this group with the natural reluctance of the older group to co-operate in an experimental procedure. Estimations of serum triglyceride, total cholesterol, HDL, LDL and VLDL cholesterol were performed as the index of lipid metabolism and calcium, phosphate and magnesium were selected as the representatives of osteogenic minerals. Estimation of fasting sugar and urea were performed as general index for carbohydrate and nitrogen metabolism and creatinine as an index for renal function. The mean fasting serum TG, HDL and VLDL values are significantly high $(p<0.01)$ and the LDL value is significantly low in the patients with osteoporosis in relation to the normal control group. Osteogenic minerals represented by calcium, phosphate and magnesium show significant elevation $(\mathrm{p}<0.01)$ of mean serum concentration in the osteoporotic group than the normal control group. The mean fasting serum concentration of glucose in the osteoporotic group show very highly significant elevation in relation to normal control group. In both the groups, glucose level within the range of 60 $110 \mathrm{mg} / \mathrm{dL}$. Urea level in serum of osteoporotic group is also elevated than normal control. Serum creatinine levels in osteoporotic group shows a normal range, which excludes the probability of renal involvement in osteoporosis. The correlative part of present study shows that in the osteoporotic group the correlation between total cholesterol and magnesium is significantly increased $(r=+0.7)$ than that of normal control $(\mathrm{r}=+0.320)$. The correlation between phosphate and HDL is also increased along with correlations between calcium and magnesium in the osteoporotic group.

There is a significant relationship of phosphate with HDL and LDL cholesterol, the two opposing cholesterol carriers which are inverse to each other, whereas the relationship of triglyceride and total cholesterol is more significant with magnesium and reciprocal in nature. The primary component of osteogenic minerals, calcium shows an increase in correlation with magnesium, but no change in correlation with phosphate in the osteoporotic group [Fig 2(A)].

Filiz has demonstrated that patients with fractures had lower levels of TC, TG, LDL-C than the patients without fractures ${ }^{16}$. In our study LDL cholesterol was significantly low, but there was significant increase in Triglyceride Level (TG) and no significant difference is observed between the mean serum total cholesterol values in the two groups, as most of the cases were found without fractures after radiological evaluation. However, the total cholesterol values in the osteoporotic group is apparently $6.07 \%$ lower than the mean total cholesterol in the normal control group.

From most of the available reports on the previous works on osteoporosis by different workers, it emerges out that osteoporosis specially shown in cases of postmenopausal age group is often associated with lipid metabolism disorders in the form of hyperlipidemia and atherosclerotic 
complications. ${ }^{17}$ Our study corroborate with the findings of Parhami F, Garfinkel A et al. The reports on the serum mineral status appear to be relatively more ambiguous than that of lipid metabolism studies. But among the ambiguity the commonness is that in osteoporotic situations, although the mineral profile of bone is much altered towards the loss of mechanical strength, the serum mineral profile is not proportionately deviated specially shown in situations of age related osteoporotic changes. ${ }^{18}$ These two basic informations on the relationship of osteoporosis with serum lipids and minerals lead us to propose that osteoporosis has more probability to be linked up with altered lipid and mineral metabolism with increase in age where the hormonal component may share a common stem. The changing hormonal component of the mineral metabolism is more targeted on metabolism of minerals in bone rather than minerals in circulation. The proposed probability may be one of the explanations of relative absence of drastic alteration in serum mineral profile in presence of gross structural and functional alteration in bone mineral content in osteoporosis.

\section{CONCLUSION}

All these observations suggest that no drastic alteration is observed in the serum lipid and mineral profile in osteoporosis. Although minor changes in lipid and mineral metabolism have been observed in osteoporotic subjects, metabolic disorder of bone due to natural aging process like any other living tissues, still seems to be the most plausible explanation for osteoporosis. Larger and more elaborate studies are required to precisely establish the relationship between changes in lipid profile and osteogenic mineral status in osteoporotic individuals. From the available literature on the problems of osteoporosis, dyslipidemias and mineral imbalances, it is felt to be very tough to have a concerted view on the three conditions as most of the works treated them as individual entities.

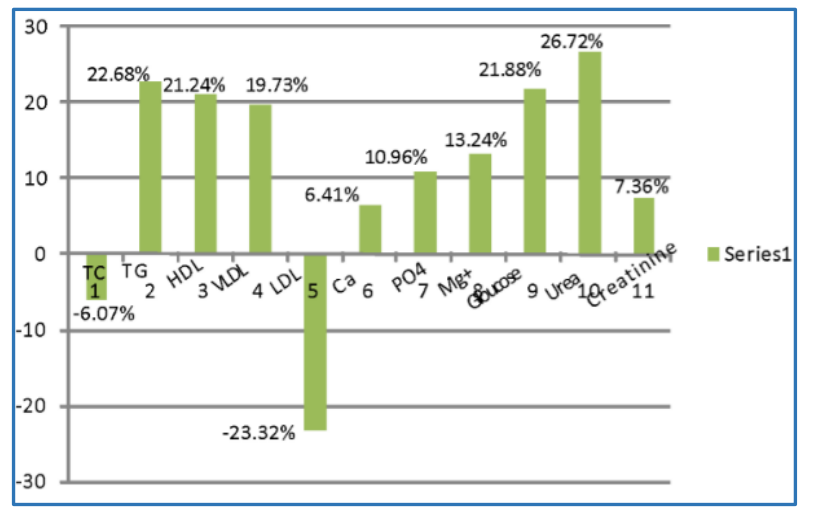

Fig. (I-A)

This figure indicates the mean percent displacement of different parameters in the osteoporotic group from the normal control baseline.

The mean fasting serum TG, HDL and VLDL values are significantly high $(p<0.01)$ and LDL value is significantly low in the patients with osteoporosis in relation to the normal control group. Similarly, osteogenic mineral concentration in serum show significant elevation in osteoporotic group [shown in Fig. (I-B, C, D).

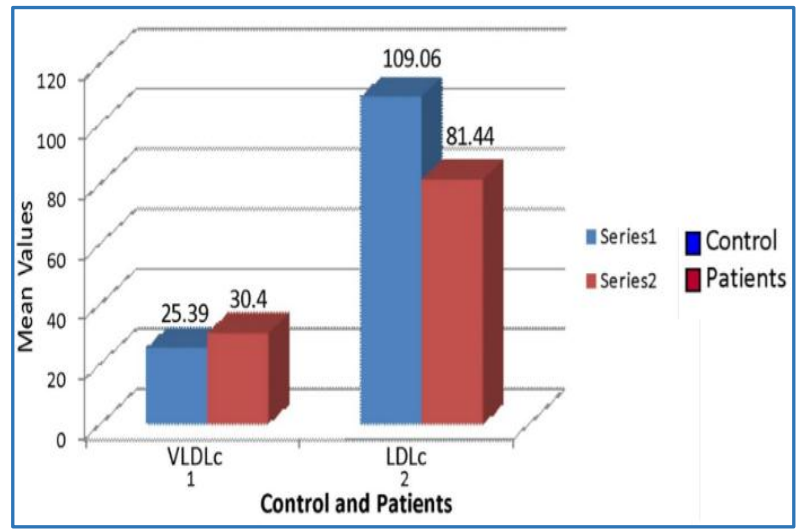

Fig. (I-B)

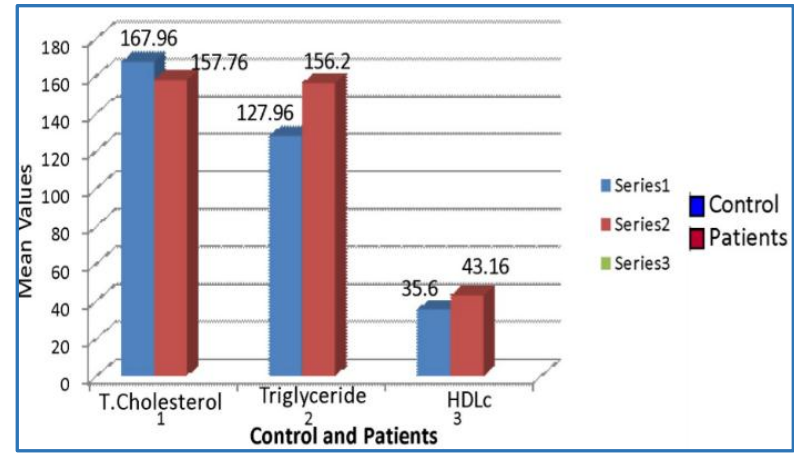

Fig. (I-C)

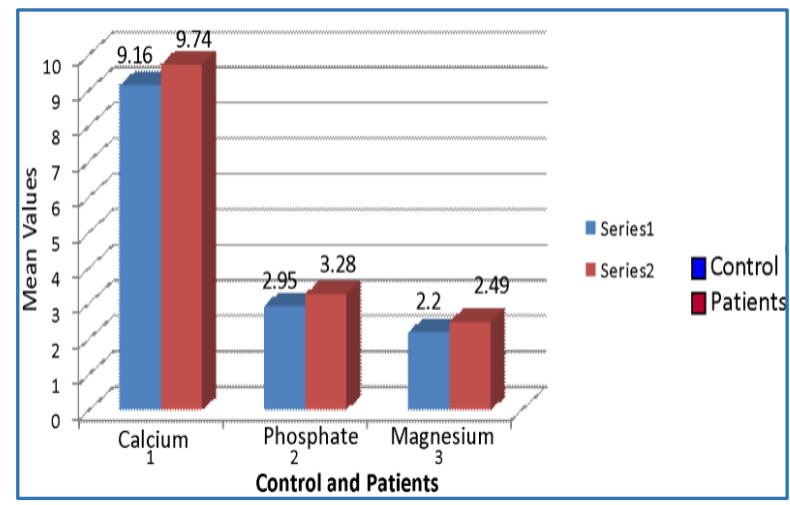

Fig. (I-D)

A schematic representation of the relationship between osteogenic mineral and lipid fractions with significant alterations in correlation coefficient in the osteoporotic group.

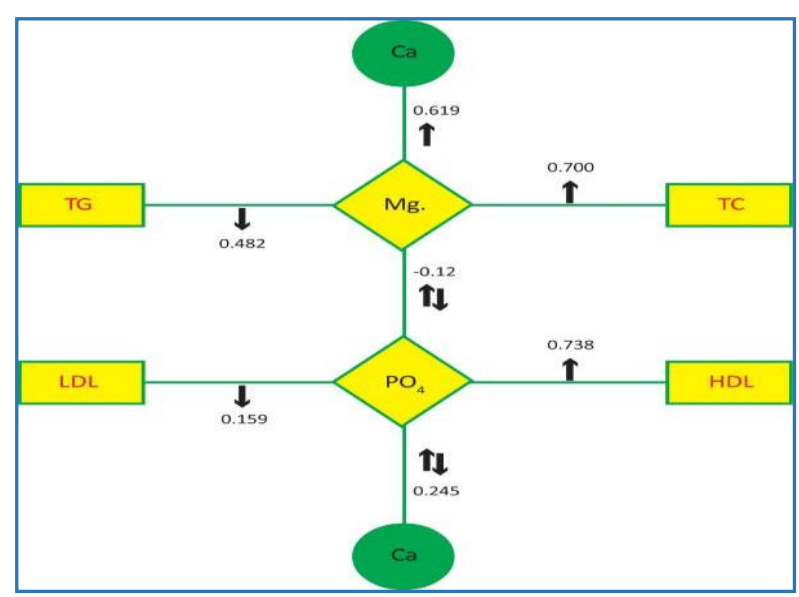

Fig. 2(A) 
During the correlation analysis of the observations of the present study, the relationship between osteogenic mineral axis of $\mathrm{Ca}^{2+}, \mathrm{Mg}^{2+}$ and $\mathrm{PO}_{4}{ }^{3-}$ is presented against the lipid profile components represented by TG, TC, HDL and LDL in the osteoporotic group, it is observed that the relationship of Phosphate with HDL and LDL, the two opposite cholesterol carriers are inversed to each other, whereas the relationship of TG and total cholesterol is more significant with magnesium and also reciprocal is nature. The calcium shows an increase in correlation with magnesium, but no change in correlation with phosphate.

\begin{tabular}{|c|c|c|c|}
\hline \multicolumn{4}{|c|}{ NORMAL GROUP } \\
\hline C.I. & No. of Pt & $\%$ & Rel. Freq. \\
\hline $0-50$ & 0 & 0 & 0 \\
\hline $51-100$ & 0 & 0 & 0 \\
\hline $101-150$ & 7 & 28 & 0.033 \\
\hline $151-200$ & 14 & 56 & 0.597 \\
\hline 201-250 & 4 & 16 & 0.197 \\
\hline \multicolumn{4}{|c|}{$\begin{array}{l}\text { Mode class : } 151-200 \mathrm{mg} / \mathrm{dl} \\
\text { St Dev } \pm 32.23 \\
\text { S.E.M : } \pm 6.44 \\
\text { Co-efficient Variant : } 19.18\end{array}$} \\
\hline \multicolumn{4}{|c|}{ PATIENT GROUP } \\
\hline C.I. & No. of Pt & $\%$ & Rel. Freq. \\
\hline $0-50$ & 0 & 0 & 0 \\
\hline $51-100$ & 2 & 8 & 0.042 \\
\hline $101-150$ & 9 & 36 & 0.303 \\
\hline $151-200$ & 12 & 48 & 0.522 \\
\hline $201-250$ & 1 & 4 & 0.063 \\
\hline $251-300$ & 1 & 4 & 0.068 \\
\hline \multicolumn{4}{|c|}{$\begin{array}{l}\text { Mode class : } 151-200 \mathrm{mg} / \mathrm{dL} \\
\text { St Dev } \pm 42.70 \\
\text { S.E.M : } \pm 8.54 \\
\text { Co-efficient Variant : } 27.06\end{array}$} \\
\hline \multicolumn{4}{|c|}{$\begin{array}{c}\text { Table 1: Distribution Total Cholesterol in } \\
\text { Normal and Patient Groups }\end{array}$} \\
\hline
\end{tabular}

\begin{tabular}{|c|c|c|c|}
\hline \multicolumn{4}{|c|}{ NORMAL GROUP } \\
\hline C.I. & No. of Pt & $\%$ & Rel. Freq. \\
\hline $0-50$ & 0 & 0 & 0 \\
\hline $51-100$ & 7 & 28 & 0.185 \\
\hline $101-150$ & 13 & 52 & 0.542 \\
\hline $151-200$ & 5 & 20 & 0.272 \\
\hline $201-250$ & 0 & 0 & 0 \\
\hline \multicolumn{4}{|c|}{$\begin{array}{c}\text { Mode class : } 101-150 \mathrm{mg} / \mathrm{dL} \\
\text { St Dev } \pm 34.45 \\
\text { S.E.M : } \pm 6.89 \\
\text { Co-efficient Variant : } 27.05\end{array}$} \\
\hline \multicolumn{4}{|c|}{ PATIENT GROUP } \\
\hline C.I. & No. of Pt & $\%$ & Rel. Freq. \\
\hline $0-50$ & 0 & 0 & 0 \\
\hline $51-100$ & 1 & 4 & 0.023 \\
\hline $101-150$ & 10 & 40 & 0.325 \\
\hline $151-200$ & 11 & 44 & 0.494 \\
\hline $201-250$ & 3 & 12 & 0.155 \\
\hline \multicolumn{4}{|c|}{$\begin{array}{c}\text { Mode class : } 151-200 \mathrm{mg} / \mathrm{dL} \\
\text { St Dev } \pm 34.43 \\
\text { S.E.M }: \pm 6.88 \\
\text { Co-efficient Variant : } 22.0\end{array}$} \\
\hline \multicolumn{4}{|c|}{$\begin{array}{c}\text { Table 2: Distribution of Serum Triacylglycerol } \\
\text { on Normal and Patient Groups }\end{array}$} \\
\hline
\end{tabular}

\begin{tabular}{|c|c|c|c|}
\hline \multicolumn{5}{|c|}{ NORMAL GROUP } \\
\hline C.I. & No. of Pt & $\%$ & Rel. Freq. \\
\hline $0-10$ & 0 & 0 & 0 \\
\hline $11-20$ & 0 & 0 & 0 \\
\hline $21-30$ & 2 & 8 & 0.059 \\
\hline $31-40$ & 18 & 72 & 0.702 \\
\hline $41-50$ & 5 & 20 & 0.238 \\
\hline \multicolumn{4}{|c|}{ Mode class : 31-40mg/dL } \\
St Dev \pm 500 \\
S.E.M : \pm 1.00 \\
Co-efficient Variant : 14.0 \\
PATIENT GROUP \\
\hline
\end{tabular}

\begin{tabular}{|c|c|c|c|}
\hline C.I. & No. of Pt & $\%$ & Rel. Freq. \\
\hline $0-10$ & 0 & 0 & 0 \\
\hline $11-20$ & 1 & 4 & 0.012 \\
\hline $21-30$ & 0 & 0 & 0 \\
\hline $31-40$ & 10 & 40 & 0.332 \\
\hline $41-50$ & 7 & 28 & 0.281 \\
\hline $51-60$ & 5 & 20 & 0.260 \\
\hline $61-70$ & 2 & 8 & 0.113 \\
\hline $71-80$ & 0 & 0 & 00 \\
\hline \multicolumn{4}{|c|}{ Mode class : $31-40 \mathrm{mg} / \mathrm{dL}$} \\
St Dev \pm 11.36 \\
S.E.M : \pm 2.27 \\
Co-efficient Variant : 26.3 \\
\hline \multicolumn{4}{|c|}{ Table 3: Distribution of Serum HDL Cholesterol } \\
in Normal and Patient Groups
\end{tabular}

\begin{tabular}{|c|c|c|c|}
\hline \multicolumn{4}{|c|}{ NORMAL GROUP } \\
\hline C.I. & No. of Pt & $\%$ & Rel. Freq. \\
\hline $0-10$ & 0 & 0 & 0 \\
\hline $11-20$ & 7 & 28 & 0.178 \\
\hline $21-20$ & 13 & 52 & 0.550 \\
\hline $31-40$ & 5 & 20 & 0.271 \\
\hline $41-50$ & 0 & 0 & 0 \\
\hline
\end{tabular}

Mode class : $21-30 \mathrm{mg} / \mathrm{dL}$

St Dev \pm 7.165

S.E.M : \pm 1.43

Co-efficient Variant : 28.20

PATIENT GROUP

\begin{tabular}{|c|c|c|c|}
\hline C.I. & No. of Pt & $\%$ & Rel. Freq. \\
\hline $0-10$ & 0 & 0 & 0 \\
\hline $11-20$ & 2 & 8 & 0.05 \\
\hline $21-30$ & 12 & 48 & 0.410 \\
\hline $31-40$ & 10 & 40 & 0.484 \\
\hline $41-50$ & 1 & 4 & 0.053 \\
\hline
\end{tabular}

Mode class : $21-30 \mathrm{mg} / \mathrm{dL}$

St Dev \pm 7.05

S.E.M : \pm 1.41

Co-efficient Variant : 23.19

Table 4: Distribution of Serum VLDL Cholesterol in Normal and Patient Groups

\begin{tabular}{|c|c|c|c|}
\hline \multicolumn{7}{|c|}{ NORMAL GROUP } \\
\hline C.I. & No. of Pt & $\%$ & Rel. Freq. \\
\hline $0-50$ & 0 & 0 & 0 \\
\hline $51-100$ & 7 & 28 & 0.195 \\
\hline $101-150$ & 17 & 68 & 0.748 \\
\hline $151-200$ & 1 & 4 & 0.055 \\
\hline $201-250$ & 0 & 0 & 0 \\
\hline \multicolumn{5}{|c|}{ Mode class : 101-150mg/dL } \\
St Dev \pm 23.39 \\
S.E.M : \pm 4.67 \\
Co-efficient Variant : 21.44 \\
PATIENT GROUP \\
\hline C.I. & No. of Pt & $\%$ Rel. Freq. \\
\hline $0-50$ & 3 & 12 & 0.059 \\
\hline $51-100$ & 14 & 56 & 0.521 \\
\hline $101-150$ & 8 & 32 & 0.419 \\
\hline $151-200$ & 0 & 0 & 0 \\
\hline $201-250$ & 0 & 0 & 0 \\
\hline \multicolumn{5}{|c|}{ Mode class : $51-100 \mathrm{mg} / \mathrm{dL}$} \\
\end{tabular}




\begin{tabular}{|c|c|c|c|}
\hline \multicolumn{4}{|c|}{$\begin{array}{c}\text { S.E.M : } \pm 4.87 \\
\text { Co-efficient Variant : } 29.92\end{array}$} \\
\hline \multicolumn{4}{|c|}{$\begin{array}{c}\text { Table 5: Distribution of Serum LDL Cholesterol } \\
\text { in Normal and Patient Groups }\end{array}$} \\
\hline \multicolumn{4}{|c|}{ NORMAL GROUP } \\
\hline C.I. & No. of Pt & $\%$ & Rel. Freq. \\
\hline $7.1-8$ & 3 & 12 & 0.104 \\
\hline 8.1.-9 & 15 & 60 & 0.589 \\
\hline $9.1-10$ & 7 & 28 & 0.305 \\
\hline $10.1-11$ & 0 & 0 & 0 \\
\hline 11.1.-12 & 0 & 0 & 0 \\
\hline \multicolumn{4}{|c|}{$\begin{array}{c}\text { Mode class : } 8.1-9 \mathrm{mg} / \mathrm{dL} \\
\text { St Dev } \pm 0.624 \\
\text { S.E.M : } \underline{\underline{ \pm}} 0.124 \\
\text { Co-efficient Variant : } 6.81\end{array}$} \\
\hline C.I. & No. of Pt & $\%$ & Rel. Freq. \\
\hline 7.1-8 & 0 & 0 & 0 \\
\hline $8.1-9$ & 2 & 8 & 0.072 \\
\hline $9.1-10$ & 11 & 44 & 0.425 \\
\hline $10.1-11$ & 12 & 48 & 0.501 \\
\hline 11.1-12 & 0 & 0 & 0 \\
\hline \multicolumn{4}{|c|}{$\begin{array}{l}\text { Mode class : } 10.1-11 \mathrm{mg} / \mathrm{dL} \\
\text { St Dev } \pm 0.506 \\
\text { S.E.M : } \pm 0.101 \\
\text { Co-efficient Variant : } 5.20\end{array}$} \\
\hline \multicolumn{4}{|c|}{$\begin{array}{l}\text { Table 6: Distribution of Serum Calcium } \\
\text { in Normal and Patient Groups }\end{array}$} \\
\hline
\end{tabular}

\begin{tabular}{|c|c|c|c|}
\hline \multicolumn{3}{|c|}{ Co-efficient Variant : 10.1} \\
\hline C.I. & No. of Pt & $\%$ & Rel. Freq. \\
\hline $1.6-1.9$ & 0 & 0 & 0 \\
\hline $2.0-2.3$ & 11 & 44 & 0.323 \\
\hline $2.4-2.7$ & 8 & 32 & 0.323 \\
\hline $2.8-3.1$ & 4 & 16 & 0.181 \\
\hline $3.2-3.5$ & 2 & 8 & 0.104 \\
\hline \multicolumn{4}{|c|}{$\begin{array}{c}\text { Mode class : } 2-23 \mathrm{mg} / \mathrm{dL} \\
\text { St Dev } \pm 0.324 \\
\text { S.E.M }: \pm 0.064 \\
\text { Co-efficient Variant : } 13.0\end{array}$} \\
\hline \multicolumn{4}{|c|}{ Table 8: Distribution of Serum LDL Magnesium } \\
in Normal and Patient Groups
\end{tabular}

\begin{tabular}{|c|c|c|c|}
\hline \multicolumn{4}{|c|}{ NORMAL GROUP } \\
\hline C.I. & No. of Pt & $\%$ & Rel. Freq. \\
\hline $1.2-1.9$ & 1 & 4 & 0.016 \\
\hline $2.0-2.7$ & 8 & 32 & 0.259 \\
\hline $2.8-3.5$ & 12 & 48 & 0.515 \\
\hline $3.6-4.3$ & 4 & 16 & 0.208 \\
\hline 4.4. & 0 & 0 & 0 \\
\hline \multicolumn{4}{|c|}{$\begin{array}{c}\text { Mode class : } 2.8-35 \mathrm{mg} / \mathrm{dL} \\
\text { St Dev } \pm 0.66 \\
\text { S.E.M : } \pm 0.132 \\
\text { Co-efficient Variant : } 22.40\end{array}$} \\
\hline \multicolumn{4}{|c|}{ PATIENT GROUP } \\
\hline C.I. & No. of Pt & $\%$ & Rel. Freq. \\
\hline $1.2-1.9$ & 0 & 0 & 0 \\
\hline $2.0-2.7$ & 3 & 12 & 0.096 \\
\hline $1.8-3.5$ & 15 & 60 & 0.582 \\
\hline $3.6-4.3$ & 7 & 28 & 0.320 \\
\hline $4.4-5.1$ & 0 & 0 & 0 \\
\hline \multicolumn{4}{|c|}{$\begin{array}{l}\text { Mode class : } 2.8-3.5 \mathrm{mg} / \mathrm{dL} \\
\text { St Dev } \pm 0.414 \\
\text { S.E.M : } \pm 0.082 \\
\text { Co-efficient Variant : } 12.62\end{array}$} \\
\hline & $\begin{array}{r}\text { Table 7: } L \\
\text { in }\end{array}$ & $\overline{r i b}$ & $\begin{array}{l}\text { LDL Phosphate } \\
\text { Groups }\end{array}$ \\
\hline
\end{tabular}

\begin{tabular}{|c|c|c|c|}
\hline \multicolumn{5}{|c|}{ NORMAL GROUP } \\
\hline C.I. & No. of Pt & $\%$ & Rel. Freq. \\
\hline $60-70$ & 2 & 8 & 0.065 \\
\hline $71-80$ & 15 & 60 & 0.583 \\
\hline $81-90$ & 6 & 24 & 0.257 \\
\hline $91-100$ & 2 & 8 & 0.094 \\
\hline $101-200$ & 0 & 0 & 0 \\
\hline \multicolumn{4}{c}{ Mode class : $71-80 \mathrm{mg} / \mathrm{dL}$} \\
St Dev \pm 7.46 \\
S.E.M : \pm 1.49 \\
Co-efficient Variant : 9.34
\end{tabular}

\section{PATIENT GROUP}

\begin{tabular}{|c|c|c|c|}
\hline C.I. & No. of Pt & $\%$ & Rel. Fre \\
\hline $60-70$ & 0 & 0 & 0 \\
\hline $71-80$ & 0 & 0 & 0 \\
\hline $81-90$ & 9 & 36 & 0.314 \\
\hline $91-100$ & 6 & 24 & 0.239 \\
\hline $101-200$ & 10 & 40 & 0.446 \\
\hline
\end{tabular}

Mode class : $100-200 \mathrm{mg} / \mathrm{dL}$

St Dev \pm 11.56

S.E.M : \pm 2.31

Co-efficient Variant : 11.87

Table 9: Distribution of Serum Glucose in Normal and Patient Groups

\begin{tabular}{|c|c|c|c|}
\hline \multicolumn{4}{|c|}{ NORMAL GROUP } \\
\hline C.I. & No. of Pt & $\%$ & Rel. Freq. \\
\hline $21-25$ & 12 & 48 & 0.440 \\
\hline $26-30$ & 12 & 48 & 0.509 \\
\hline $31-35$ & 1 & 4 & 0.049 \\
\hline $36-40$ & 0 & 0 & 0 \\
\hline $41-45$ & 0 & 0 & 0 \\
\hline \multicolumn{4}{|c|}{ Mode class : $26-30 \mathrm{mg} / \mathrm{dL}$} \\
St Dev \pm 2.57 \\
C.E.M : \pm 0.514 \\
\hline \multicolumn{4}{|c|}{ PATIENT GROUP } \\
\hline C.I. & No. of Pt & $\%$ & Rel. Freq. \\
\hline $21-25$ & 5 & 20 & 0.139 \\
\hline $26-30$ & 6 & 24 & 0.206 \\
\hline $31-35$ & 5 & 20 & 0.201 \\
\hline $36-40$ & 8 & 32 & 0.372 \\
\hline $41-45$ & 1 & 4 & 0.081 \\
\hline
\end{tabular}

\begin{tabular}{|c|c|c|c|}
\hline \multicolumn{3}{|c|}{ NORMAL GROUP } \\
\hline C.I. & No. of Pt & $\%$ & Rel. Freq. \\
\hline $1.6-1.9$ & 3 & 12 & 0.099 \\
\hline $2.0-2.3$ & 12 & 48 & 0.459 \\
\hline $2.4-2.7$ & 10 & 40 & 0.441 \\
\hline $2.8-3.1$ & 0 & 0 & 0 \\
\hline $3.2-3.5$ & 0 & 0 & 0 \\
\hline \multicolumn{4}{|c|}{ Mode class : $2-23 \mathrm{mg} / \mathrm{dL}$} \\
St Dev \pm 0.222 \\
S.E.M $: \pm 0.044$ \\
\hline
\end{tabular}




\begin{tabular}{|c|}
\hline Mode class : $36-40 \mathrm{mg} / \mathrm{dL}$ \\
St Dev \pm 9.29 \\
S.E.M : \pm 1.85 \\
Co-efficient Variant : 28.1 \\
\hline Table 10: Distribution of Serum Urea \\
in Normal and Patient Groups
\end{tabular}

\begin{tabular}{|c|c|c|c|}
\hline \multicolumn{4}{|c|}{ NORMAL GROUP } \\
\hline C.I. & No. of Pt & $\%$ & Rel. Freq. \\
\hline $0.5-0.7$ & 3 & 12 & 0.088 \\
\hline $0.8-1.0$ & 14 & 56 & 0.529 \\
\hline 1.1-1.3 & 8 & 32 & 0.382 \\
\hline $1.4-1.6$ & 0 & 0 & 0 \\
\hline $1.7-1.9$ & 0 & 0 & 0 \\
\hline \multicolumn{4}{|c|}{$\begin{array}{l}\text { Mode class : } 0.8-1.0 \mathrm{mg} / \mathrm{dL} \\
\text { St Dev } \pm 0.177 \\
\text { S.E.M : } \pm 0.035 \\
\text { Co-efficient Variant : } 17.44 \\
\text { PATIENT GROUP }\end{array}$} \\
\hline C.I. & No. of Pt & $\%$ & Rel. Freq. \\
\hline $0.5-0.7$ & 1 & 4 & 0.027 \\
\hline $0.8-1.0$ & 13 & 52 & 0.458 \\
\hline $1.1-1.3$ & 10 & 40 & 0.458 \\
\hline 1.4-1.6 & 1 & 4 & 0.054 \\
\hline $1.7-1.9$ & 0 & 0 & 0 \\
\hline \multicolumn{4}{|c|}{$\begin{array}{l}\text { Mode class : } 0.8-1.0 \mathrm{mg} / \mathrm{dL} \\
\text { St Dev } \pm 0.161 \\
\text { S.E.M : } \pm 0.032 \\
\text { Co-efficient Variant : } 16.95\end{array}$} \\
\hline \multicolumn{4}{|c|}{$\begin{array}{c}\text { Table 11: Distribution of Serum Creatinine } \\
\text { in Normal and Patient Groups }\end{array}$} \\
\hline
\end{tabular}

\begin{tabular}{|c|c|c|}
\hline Parameters & Normal & Patient \\
\hline Serum Magnesium & $\mathrm{P}<0.005$ & $\mathrm{P}<0.01$ \\
\hline Serum Calcium & $\mathrm{P}<0.0005$ & $\mathrm{P}<0.0005$ \\
\hline Serum Phosphate & $\mathrm{P}>0.01$ & $\mathrm{P}<0.025$ \\
\hline Serum Urea & $\mathrm{P}<0.005$ & $\mathrm{P}<0.01$ \\
\hline Serum Total Cholesterol & $\mathrm{P}>0.1$ & $\mathrm{P}>0.01$ \\
\hline Serum Creatinine & $\mathrm{P}>0.05$ & $\mathrm{P}>0.05$ \\
\hline Serum Triglyceride & $\mathrm{P}<-.005$ & $\mathrm{P}<0.01$ \\
\hline Serum HDLC & $\mathrm{P}<0.005$ & $\mathrm{P}<0.01$ \\
\hline Serum VLDLC & $\mathrm{P}<0.01$ & $P>0.005$ \\
\hline Serum LDLC & $\mathrm{P}<0.0005$ & $\mathrm{P}<0.01$ \\
\hline
\end{tabular}

\section{ACKNOWLEDGEMENT}

We sincerely thank Dr. R. K. Mahanta, Professor and Head of the Department of Biochemistry, Tezpur Medical College, Tezpur, Assam, for his valuable suggestions and guidance throughout the period of this study.

\section{REFERENCES}

1. Solomon L. Bone loss in ageing individuals. Orthopaedics 1978;6:121.

2. Hodsman AB, Drost DJ, Goldenberg J. Reduced vertebral fracture rates in osteoporotic patients responding to fluoride treatment with an increasing vertebral bone mineral density. In: Christian Sen C, overgaard K, eds. Osteoporosis. Copenhagen osteopress APS, 1990;14841485.

3. The Merk manual of diagnosis and therapy. Section 5 Musculoskeletal and connective tissue disorders. chapter 57, osteoporosis. pg 450.

4. Mercer's orthopaedic surgery by Robert Duthie and George Bentley, 9th edn:pg 312.

5. Orimo $\mathrm{H}$, Shiraki $\mathrm{M}$, Inoue $\mathrm{S}$. Oestrogen and bone. Osteoporosis Int 1993;3(I):153-156.

6. Brown EM. Fluoride and the therapy of osteoporosis. J Clin Endocrinol Metab 1989;69(5):929-931.

7. Parfitt AM. Bone remodelling and bone loss; understanding the pathophysiology of osteoporosis. Clin Obstet Gynecol 1987;30(4):789-811.

8. Melsen B, Melsen F, Mosekilde L, et al. Histomorphometric analysis of normal bone from the iliac crest. Acta path Micr Scand Sect A 1978;86:70-81.

9. Satynarayana U, Chakrapani U. Textbook of Biochemistry. $4^{\text {th }}$ edition:pg 404.

10. Harrison HE, Harrison HC. The interaction of vitamin D and $\mathrm{PTH}$ on $\mathrm{Ca}, \mathrm{P}$ and $\mathrm{Mg}$ homeostasis in the rat. Metabolism 1964;13(10):952-58.

11. Macleod John ed, Davidson's principles and practice of Medicine. 14th ed:pp 70.

12. Mazzuoli GF, D’ Erasmo E, Minisola S, et al. Pathogenic aspects of involutional osteoporosis. Clin Rheumatol 1989;8(2):22-29.

13. Osteoporosis: Diagnosis and treatment. David J Sartosis. Copy right by Marcel Dekker Inc., New York, Indian reprint 2000;pg 6-9.

14 National institutes of health consensus development conference statement on osteoporosis. JAMA 1984;252:799-802.

15 Apley's System of orthopaedics and fractures. A graham Apley, Lousis Solomon. $8^{\text {th }}$ ed:pp 185.

16 Filiz Sivas, Ebru Alemdaroglu, Eda Elverici, et al. Serum lipid profile: its relationship with osteoporotic vertebrae fractures and bone mineral density in Turkish postmenopausal women. Rheumatology International 2009;29(8):885-890.

17 Parhami F, Garfinkel A, Demer LL. Arterioscler Thromb Vasc Biol. American Heart Association 2000;20(11):2346-8.

18 Samual L Turek. Orthopaedics principles and their application. JB Lippincott, Philadelphia, Chapter 9, 4th Ed:pp 241. 